\title{
歩行振動からみた CLT 造床のスパン表の例示 \\ PRESENTATION OF EXAMPLE OF SPAN TABLE OF CROSS LAMINATED TIMBER FLOOR FROM THE VIEWPOINT OF WALKING VIBRATION
}

\author{
小山雄 平*1, 福田 眞太郎*2, 横山 裕*3 \\ Yuhei KOYAMA, Shintaro FUKUDA and Yutaka YOKOYAMA
}

\begin{abstract}
Walking vibration can cause complaints on building floor, especially on timber floor. However, its evaluation and estimation method are still not established.

In this study, as a first step toward establishing these methods, the vibration characteristics of a CLT floor subjected to walking vibrations was measured. Then, a finite element model was also created to investigate the influence of varying material properties and boundary conditions on the vibration performance of the floor. Then, the influence of CLT floor-wall connection upon vibration characteristics was investigated.
\end{abstract}

In conclusion, the span table of CLT floor from the viewpoint of walking vibration was presented.

\section{Keywords : Walking Vibration, Cross Laminated Timber Floor, Span Table, Habitability, Finite Element Method} 歩行振動, CLT 造床, スパン表, 居住性, 有限要素法

\section{1.はじめに}

建築物の床では、床上での人間の動作により発生する振動が、居 住性の観点から問題となる場合がある。特に、日常避けられない動 作である歩行により不快な振動が発生した場合、床に問題があると 判断されるため、苦情などにつながる可能性が高くなる 1$)$ 。木造建 築物の床(以降 “木造床” と記す)は、 $\mathrm{RC}$ 造や $\mathrm{S}$ 造建築物のコンク リートスラブと比較して軽量で剛性が低いため、歩行により発生す る振動(以降 “歩行振動” と記す)に対するより一層の注意が必要で ある。

一般に、歩行振動問題は、建築物竣工後の対策は困難とされてい る。したがって、設計段階において、発生する歩行振動を的確に予 測する必要がある。しかし、木造床の歩行振動の予測方法に関して は、床振動に影響する材料の物性值や接合部の固定度などに関する 知見がほとんど蓄積されていないため、詳細な予測解析が実施され た例は非常に少ない。また、部材の断面寸法やスパンなどを用いた 簡便な予測方法についても、十分な成果が蓄積されているとはいい がたい。すなわち、木造床では、設計段階における歩行振動の予測 方法が十分に整備されていないのが実状である。

つぎに、予測した歩行振動を居住性の観点から評価するための評 価指標の現状について述べる。居住性からみた振動の評価には、こ れまで日本建築学会「建築物の振動に関する居住性能評価指針」2)
などが用いられてきたが、これらの評価指標はおもに正弦振動を用 いた研究成果に基づいており、非定常的な振動である歩行振動に適 用すると、峳しい評価となりすぎることが数多く指摘されてい る例えば 1)。これに対し、横山，黒田ら 3),4 4 は、木造の試料床を用い た検討結果に基づいて、木造床の歩行振動の評価指標を提示してい る。この評価指標では、振動数, 振幅に加え振動の継続時間の要因 が盛り込まれており、その骨子は 2018 年に改定された日本建築学 会「建築物の振動に関する居住性能評価規準」5) と一致している。

以上に述べた現状を踏まえ、本報では、木造床のうち、近年採用 事例が増加しており、かつ軸材と面材からなる在来軸組構法や枠組 壁構法の床などと比較して予測解析が容易と思われる CLT(Cross Laminated Timber)造床を対象に、歩行振動の測定と予測解析を実 施し、両者の結果の比較から測定結果を再現できる解析方法を確立 する。さらに、解析モデルのスパンを種々変化させて求まる歩行振 動を上述の評価指標と照合することより、設計に有用な資料の 1 つ であるスパン表を例示する。

なお、本報の一部は、日本建築学会大会にて発表している 6$), 7) 。$

\section{2. 目的, 範囲}

本報は、木造床における歩行振動の予測評価の枠組み構築を最終 的な目的とした研究の第一段階として、CLT 造床を対象に、歩行

\footnotetext{
*1 東京工業大学環境・社会理工学院建築学系 修士 (工学)

*2 東京工業大学環境・社会理工学院建築学系 助教・博士 (工学)

*3 東京工業大学環境・社会理工学院建築学系 教授・工博
}

Dept. of Architecture and Building Eng., School of Environment and Society, Tokyo Institute of Technology, M.Eng.

Assist. Prof., Dept. of Architecture and Building Eng. School of Environment and Society, Tokyo Institute of Technology, Dr.Eng.

Prof., Dept. of Architecture and Building Eng., School of Environment and Society, Tokyo Institute of Technology, Dr.Eng. 
振動の予測方法確立のための知見を蓄積するとともに、木造床の歩 行振動の評価指標を適用してスパン表を例示することを目的として いる。

本研究では、1 人の歩行により発生する鉛直方向の床振動を、歩 行者と同一の床上にいる他の人間が感じた場合の評価を対象とする こととする。

\section{3. 既往の研究}

木造床の歩行振動の評価指標を提示した研究例としては、横山, 黒田ら 3,4)が挙げられる。この研究では、振動性状が種々異なる木 造の試料床を用い、官能検查手法を適用して、歩行振動に対する住 居の居室を想定した場合の人間の評価を定量化している。また、人 間の評価と検查時に検查員に入力した歩行振動との関係を検討し、 加速度・時間曲線から下式にしたがって算出される $V L T$ を、人間 の評価と対応する物理的指標(以降 “性能值” と記す) として提示し ている。

$$
\begin{aligned}
& V L T=V L_{\max }+20 \log _{10} T^{1 / 4} \\
& \text { ここで、 } V L_{\max }: V L \text { の最大值 }(\mathrm{dB}) \\
& V L \text { : 下式で得られる } a_{r m s}^{\prime} \text { のレベル換算值 }(\mathrm{dB}) \\
& V L=20 \log _{10}\left(a_{\text {rms }}^{\prime} / \text { a orms }\right)
\end{aligned}
$$

Fig. 1 に、官能検査結果に基づいて構成した振動の気になり具合 に関する心理学的尺度(以降 “気になり具合評価尺度”と記す)と、 $V L T$ の関係を示す。ただし、VLT を算出する際の時定数は、松下 ら 8)を参考に $25 \mathrm{~ms}$ に変更している。図中(2)〜(7)で示寸破線は、官 能検査で用いた判断範ちゅうの気になり具合評価尺度上の位置を表 す。VLT は、人間の振動感覚の振動数特性に応じて補正した振幅 の最大值 $V L_{\max }$ と、振動の継続時間 $T$ から算出される。すなわち、 上記の結果は、歩行振動の評価には、人間が感じる振動の大きさと 長さが大きく影響していることを示唆している。しかし、現行の設 計規準や設計資料は、このような歩行振動から算出される性能值お よび評価指標を根拠として導出されたものではない。

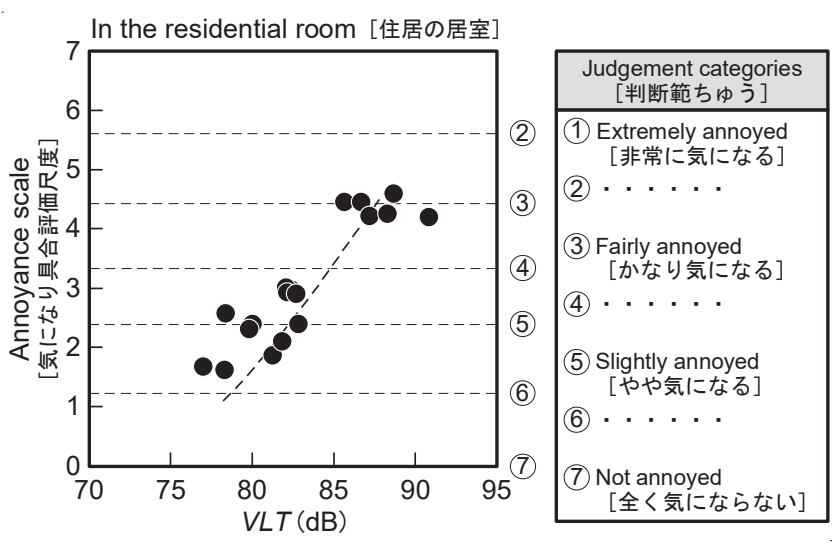

Fig. 1 Evaluation index of walking vibration on timber floor $^{3), 4)}$
例えば、日本建築学会「木質構造設計規準・同解説」9)では、振 動障害を発生させないための指標として、固定荷重や積載荷重が全 て載った場合のたわみの制限值 $1 \mathrm{~cm} \sim 0.5 \mathrm{~cm}$ を例示している。しか し、これは等分布荷重に対するたわみであり、歩行時の集中荷重に よる変形量との関係は明確になっていない。一方、海外では、集中 荷重載荷時の変形量を用いた規準が主流になっている。例えば、 Eurocode 510)では、1 次固有振動数 $8 \mathrm{~Hz}$ 以上の床を対象に、集中荷 重載荷時の変形量の荷重に対する割合と、力積 $1 \mathrm{~N} \cdot \mathrm{s}$ の衝撃荷重に 対する応答速度の推奨值を定めている。しかし、これらの変形量や 応答速度と歩行振動の関係は、明確になっていない。

この他、簡便な設計資料を提示した研究例として、CLT 造床を 対象とした $\mathrm{Hu}$ ら ${ }^{11)}$ 、在来軸組構法の床を対象とした西谷ら 12)が挙 げられる。Hu らは、CLT 造試料床を用いて実施した歩行振動に関 するアンケート結果と、試料床の 1 次固有振動数および集中荷重載 荷時の変形量との関係に基づいて、“marginal”（「よくもなく悪 くもない」の意)よりよい評価が得られる床の範囲を示寸式を、以 下のように提示している。

$$
\begin{aligned}
& d \leqq f^{1.43} / 39 \\
& \text { ここで、 } d: 1 \mathrm{kN} \text { の集中荷重載荷時の変形量 }(\mathrm{mm}) \\
& \quad f: \text { 床の } 1 \text { 次固有振動数 }(\mathrm{Hz})
\end{aligned}
$$

西谷らは、上述の横山, 黒田らの官能検查結果と、試料床の 1 次固 有振動数および集中荷重載荷時の変形量との関係から、所定の評価 水準を達成するのに必要な 1 次固有振動数と変形量の関係式を提示 している。例えば、Fig. 1 に示した判断範ちゅう“(5)やや気にな る”よりよい評価が得られる床の範囲を示寸式を、以下のように提 示している。

$$
D_{100} \leqq 0.01 f_{0}
$$

$$
\begin{gathered}
\text { ここで、 } D_{100}: 980 \mathrm{~N} \text { の集中荷重載荷時の変形量 }(\mathrm{mm}) \\
f_{0}: \text { 床の } 1 \text { 次固有振動数 }(\mathrm{Hz})
\end{gathered}
$$

これらの設計資料も、歩行振動から算出される性能值を根拠として 導出されたものではないが、本報では、スパン表例示の段階で、

$\mathrm{Hu}$ らおよび西谷らの研究成果との整合性を検討する。なお、杉 本，中村ら 13),14) も、木造校舎および木造事務所の床を対象に、歩 行振動を測定し人間の評価との関係を検討したうえで、床の 1 次固 有振動数と集中荷重載荷時の変形量を用いた設計法を提示できる可 能性を示している。

木造床の振動の予測方法に関する研究例としては、鈴木, 藤野 ら 15)-21)が挙げられる。この研究では、種々の構法の木造床を対象 に、床上にいる人間が固有振動数や減衰特性におよぼす影響を実験 的に明らかにしたうえで、有限要素法による解析結果との比較か ら、床の振動特性や衝撃荷重に対する応答などの予測方法を検討し ている。しかし、歩行振動の予測方法には言及していない。

\section{4. 研究方法}

本研究の研究方法および手順は、以下の通りである。

1)実在する CLT 造床を対象に、静的載荷試験を実施し、集中荷重 載荷時の変形特性を把握する。また、動的加振試験を実施し、固 有振動数, 振動モード, 減衰特性(以降、これらをあわせて “振 動特性”と記す)を把握する。さらに、歩行試験を実施し、歩行 振動を測定する。 


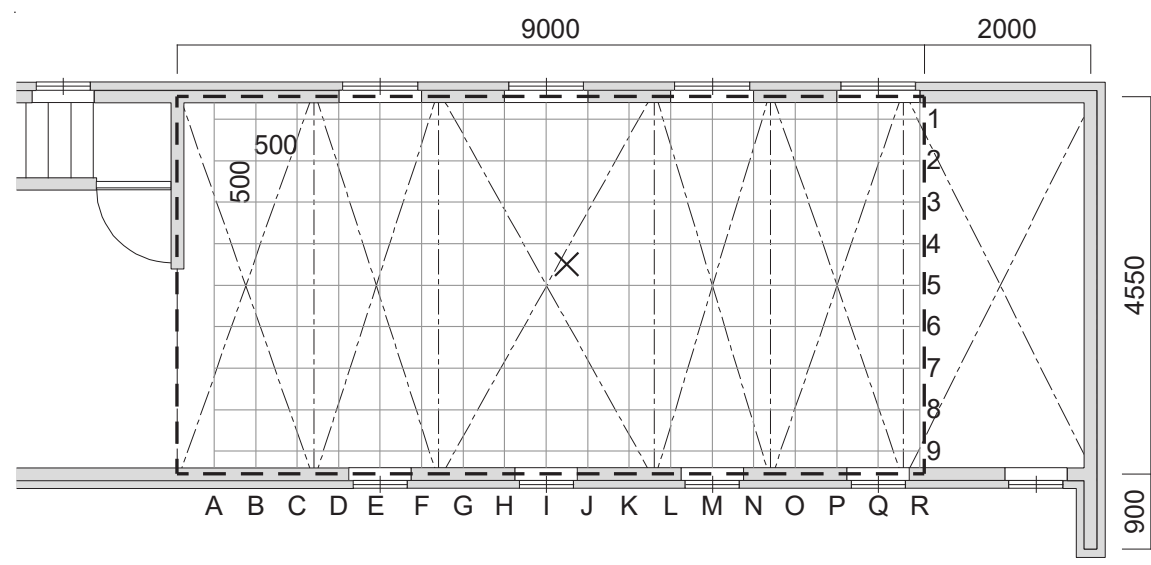

(unit : mm)
2600

$1400 \mid 1600$

2330

- - - : Investigated area $\quad$--_- :CLT floor panel $X$ :Excitation point

Fig. 2 Outline of investigated CLT floor
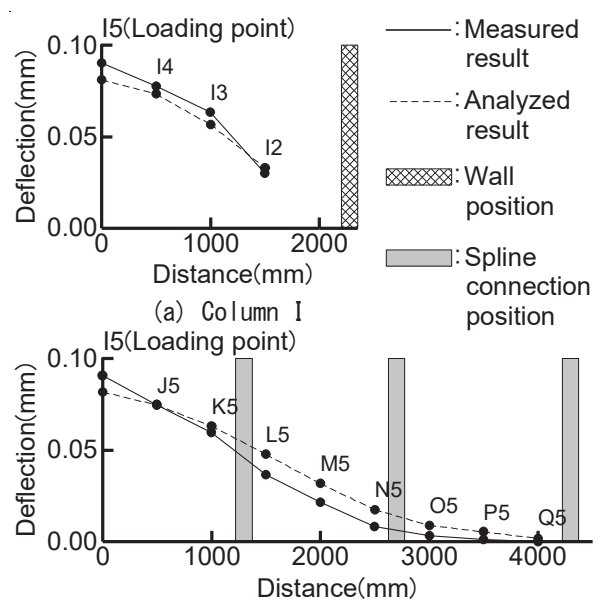

(b) Line 5

Fig. 3 Measured and analyzed result of Static Deflection (loading point: I5)
2)1)で対象とした CLT 造実在床の有限要素法による解析モデルを作 成し、材料の物性值や接合部の固定度、および入力する歩行加振 力などを種々変化させながら、解析結果と 1)での測定結果を比 較することにより、測定結果を再現できる解析方法を確立する。

3)実在床とは別に新たに作製した CLT 造試験体床を用いて、静的 載荷試験, 動的加振試験, 歩行試験を実施し、床と壁の接合部 (以降 “床壁接合部” と記す)の接合方法の違いが変形特性, 振動 特性，歩行振動におよぼす影響を把握する。

4)1＜wide>３）の検討結果に基づいて、一般的な仕様のCLT 造床の解析モ デルを作成し、スパンをパラメータとして、歩行加振力に対する 応答解析を行う。解析結果から算出される $V L T$ を横山, 黒田 ら 3),4)が提示した評価指標と照合することにより、居住性からみ た評価を求め、スパンとの関係を整理して、歩行振動からみた CLT 造床のスパン表を例示する。

\section{CLT 造実在床の変形特性, 振動特性, 歩行振動の把握}

\section{1 実在 CLT 造建築物における対象床の概要}

実在する 2 階建 CLT 造建築物の 2 階床を、対象床として選定し た。対象床の概要を、Fig. 2 に示す。対象床は、北海道産カラマツ 材製 7 層 7 プライ、厚さ $210 \mathrm{~mm}$ の CLT 床版で構成されている。 図の一点鎖線は、床版の割り付けを表す。床版のスパンは $4550 \mathrm{~mm}$ (壁心間)であり、隣接する床版同士の接合部は、上面 2 プ ライを幅 $150 \mathrm{~mm}$ 切欠き、厚さ $28 \mathrm{~mm}$ のカラマツ材製構造用合板 2 級 を長さ $140 \mathrm{~mm}$ のビスで固定し、さらに化粧材として厚さ $30 \mathrm{~mm} の$ カラマツ材製ラミナを接着固定した、スプライン接合となってい る。また、床版と壁の接合部は、1 階の壁の上に床版が載り、その 上に 2 階の壁が載った構造となっている。壁は、厚さ $150 \mathrm{~mm} の$ CLT 造で、床版と壁は、床版の下端と 1 階の壁内側、および上端 と 2 階の壁内側に、 $75 \times 75 \mathrm{~mm}$, 長さ $500 \mathrm{~mm}$ の L 字金物を、床版 1 枚あたり 4 䇢所、計 8 個取り付けて接合されている。

本研究では、この床のうち、図に破線で示す範囲を検討対象とし た。この対象範囲は、下階の壁の位置に基づいて設定したものであ る。すなわち、下階では、破線の位置に壁があり、破線に囲まれた 内部には壁がなく 1 つの部屋となっている。

対象範囲の 2 階床は、CLT 床版ほぼ 5 枚で構成されている。この
対象範囲について、試験実施にあたり、図に示すように 1〜9 行, $\mathrm{A} \sim \mathrm{R}$ 列のグリッドを $500 \mathrm{~mm}$ 間隔で設定した。本報では以降、例え ば 5 行と I 列の交点を I5 と記すこととする。また、図中横方向を行 方向、縦方向を列方向と記すこととする。なお、 5.2 で述べる静的 載荷試験と 5.3 で述べる動的加振試験は、対象床が 5 行, I 列を軸 に行方向，列方向ともおお屯線対称であることから、1〜 5 行， $\mathrm{I} \sim \mathrm{R}$ 列の範囲を対象に実施した。

\section{2 静的載荷試験}

床上の 1 点に質量 $100 \mathrm{~kg}$ の重鍾を載荷し、載荷点と、載荷点から 行方向，列方向に並ぶ各点での変形を測定した。載荷点は、I5Ｐ5 の 8 点とした。各点の変形は、変位計 $\mathrm{KEYENCE}$ 製 IL-S025,

IL-030，IL-065，LK-G155)を床版の裏面に 1 階から設置して測定 した。変位計は、1階の床で支持した。なお、I1〜P1 は、壁近傍であ るため変形は微小とみなし、測定対象から除外した。

Fig. 3 に、結果の例として、I5 載荷時の変形を実線で示す。図の (a) はI 列(I2〜I5)、(b) は 5 行 $(\mathrm{I} 5 \sim \mathrm{Q} 5)$ の結果である。また、(a)に は壁の位置、(b)にはスプライン接合部の位置も示した。図より、 CLT 床版の変形が、載荷点を中心に、行方向にも列方向にも広が っていることがわかる。ここで、(a)のI 列の結果をみると、壁か ら $700 \mathrm{~mm}$ の 12 でも比較的大きな変形が生じていることがわかる。 この変形には、壁の面外変形も影響している可能性があるが、床版 のみを解析モデル化する場合、壁の位置での床版の固定度をピン支 持とすると、壁の面外変形の影響も加味された床の変形を再現でき る可能性が高いことが推察される。一方、(b)の 5 行の結果をみる と、変形がスプライン接合部を越えて広がっており、スプライン接 合部でも応力が伝達されていることがわかる。

\section{3 動的加振試験}

はじめに、Fig. 2 に示す I1〜I5，J2〜Q5 の計 37 点の床上に加速度計 (RION 製 PV-84，PV-85)を設置したうえで、メで示寸点をハンマー で加振し、各点における加速度を同時測定した。加速度計は、薄手 の両面テープで床に固定した。ここで、加振点を対象範囲中央近傍 の I5 から行方向，列方向に半グリッドずらしたのは、I5 とすると 中央近傍に節が発生するモードの振動が励起されにくくなるためで ある。測定結果より I5 から各点への伝達関数を算出し、固有振動数 を求めるとともに、振幅比と位相差から振動モードを導出した。 


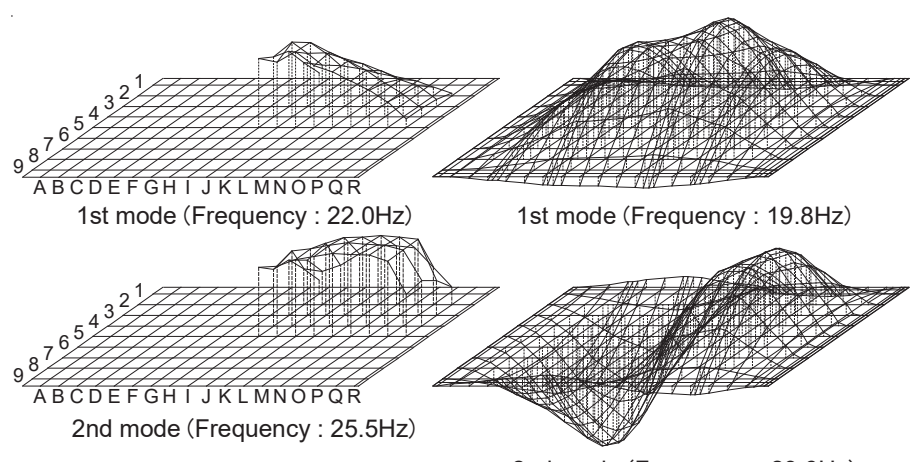

2nd mode (Frequency : $23.6 \mathrm{~Hz}$ )

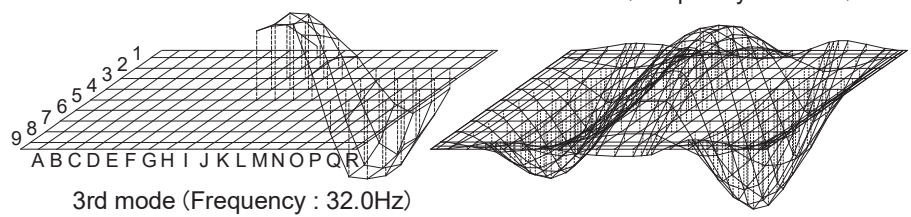

(a) Measured result

3rd mode (Frequency : $33.2 \mathrm{~Hz}$

(b) Analyzed result

Fig. 4 Measured and analyzed result of natural frequency and vibration mode

Fig. 4 の (a)に、測定の結果得られた 1 3 次の固有振動数および 振動モードを示す。図に示すように、1〜3 次の固有振動数はそれ ぞれ 22.0, 25.5, 32.0Hz であった。また、1 次モードは対象床全 体が同位相で振動するモード、2 次モードは対象床中央近傍に列方 向に振動の節が発生しこの節を堺に逆位相となるモード、3 次モー ドは対象床を 3 等分する位置近傍に列方向に 2 つの節が発生しそれ ぞれの節を堺に逆位相となるモードであることが推察された。

つぎに、対象床の減衰特性を把握する目的で、Fig. 2 にメで示寸 点をハンマーで加振した際の I5 における加速度を、以下の 3 条件 で測定した。

条件 $1:$ 床上に人間が乗っていない状態

条件 $2:$ I 5 に 1 名の人間(以降“受振者” と記す)が乗った状態

条件 3 ：I5 に 1 名，I4 に 1 名、計 2 名の受振者が乗った状態

受振者の体重は、83kg(I5)および $74 \mathrm{~kg}$ (I4)であった。また、受振者 の姿勢は立位とし、リラックスした状態で立つよう指示した。測定 は条件ごとに 5 回実施し、加速度・時間曲線の測定結果から減衰定 数を算出し平均を求めた。結果を Table 1 に示す。表に示すよう に、減衰定数は受振者数が増えるにしたがって大きくなっている。 この結果は、木造床の振動特性におよぼす人体の影響について検討 した既往の研究結果例えば 22), 15),16) と一致する。

\section{4 歩行試験}

床上に設定した歩行路を歩行者が歩行した際の振動を、所定の測 定点の床上に加速度計を設置して測定した。歩行路と測定点の組み 合わせは、Table 2 に示寸 4 種とした。歩行者は 1 名(体重 $70 \mathrm{~kg}$ ) と し、履物はくつ下とした。また、歩調は $2 \mathrm{~Hz}$ とし、メトロノーム を用いて制御した。測定は、歩行者の他に受振者 1名(体重 $83 \mathrm{~kg}$ )が測定点に乗った状態で実施した。

Table 1 Measured result of damping ratio

\begin{tabular}{|l|c|}
\hline \multicolumn{1}{|c|}{ Conditions } & Damping ratio(\%) \\
\hline No.1: with no person & 2.7 \\
\hline No.2: with one person & 4.1 \\
\hline No.3: with two people & 5.1 \\
\hline
\end{tabular}

\begin{tabular}{|c|c|c|c|c|c|c|c|}
\hline \multirow[b]{2}{*}{$\underset{\substack{\text { path } \\
\text { [歩行路] }}}{\text { Walking }} \rightarrow$} & \multirow[b]{2}{*}{$\rightarrow \begin{array}{c}\text { Measured } \\
\text { point } \\
\text { [測定点 }]\end{array}$} & \multicolumn{3}{|c|}{$V L_{\max }$} & \multicolumn{3}{|c|}{ VLT } \\
\hline & & $\begin{array}{c}\text { Measured } \\
\text { result }(\mathrm{dB}) \\
\text { [測定結果] }\end{array}$ & $\begin{array}{l}\text { Analyzed } \\
\text { result (dB) } \\
\text { [解析結果] }\end{array}$ & $\begin{array}{c}\text { Measured } \\
\text { - Analyzed } \\
(\mathrm{dB})\end{array}$ & $\begin{array}{c}\text { Measured } \\
\text { result }(\mathrm{dB}) \\
\text { [測定結果] }\end{array}$ & $\begin{array}{c}\text { Analyzed } \\
\text { result (dB) } \\
\text { [解析結果 }]\end{array}$ & \begin{tabular}{|} 
Measured \\
-Analyzed \\
(dB)
\end{tabular} \\
\hline Line $5 \rightarrow$ & 14 & 79 & 76 & 3 & 83 & 78 & 5 \\
\hline Column I $\rightarrow$ & J5 & 76 & 76 & 0 & 78 & 76 & 2 \\
\hline Column $\mathrm{M} \rightarrow$ & 15 & 74 & 73 & 1 & 76 & 73 & 3 \\
\hline Column $\mathrm{P} \rightarrow$ & 15 & 72 & 68 & 4 & 72 & 68 & 4 \\
\hline
\end{tabular}

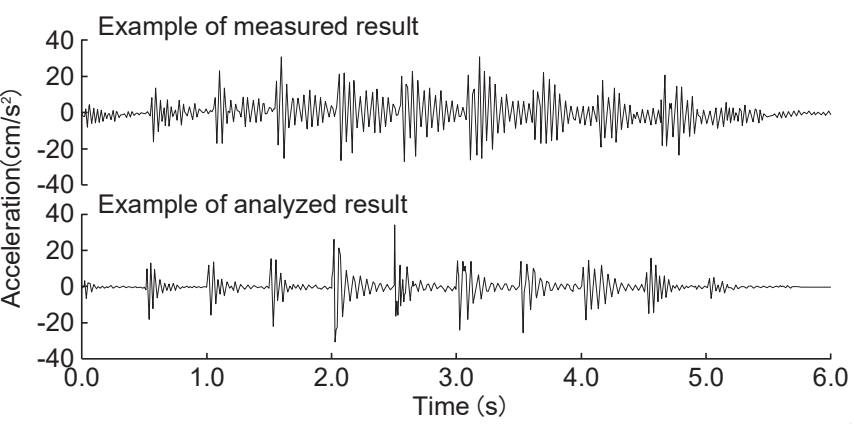

Fig. 5 Measured and analyzed result of walking vibration (Walking path: Line5, Measured point: I4)

Fig. 5 の上段に、測定結果の例として、5 行を A 列側から R 列側 に向けて歩行した際に I4 で測定された加速度・時間曲線を示す。 図より、 $0.5 \mathrm{~s}$ ごと、寸なわち 1 歩ごとに着地時の衝撃により振動が 励起されては減衰する現象が繰り返されていること、またこの振動 は歩行者が測定点に近づくにつれて大きくなり、遠ざかるにつれて 小さくなっていることがわかる。測定は歩行路，測定点の組み合わ

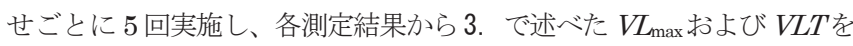
算出し平均を求めた。結果を Table 2 の「測定結果」の欄に示す。

なお、横山, 黒田ら ${ }^{3), 4)}$ の評価指標の CLT 造床に対する適用性を 確認する目的で、上記歩行試験と同一の歩行者が同一の条件で 5 行 を歩行した際に I4 で感じられる振動の気になり具合について、 Fig. 1 に示した(1)〜 (7)の判断範ちゅうにしたがって判断を求めるア ンケート調查を実施した。アンケートは、14 名の成人男女(年齢 22〜61 歳, 体重 45〜92kg)を対象に実施した。アンケートで得ら れた回答の範ちゅう番号(1)～(7)をそのまま数值 1 を 7 に置き換え、 14 名の回答の平均を求めたところ、4.2 となった。すなわち、判断 範ちゅう(4)と(5)の間の評価となった。一方、歩行路 5 行，測定点 I4 での VLTの測定結果は Table 2 に示寸通り $83 \mathrm{~dB}$ であり、この值 をFig. 1 と照合すると判断範ちゅう(4)と（5)の間の評価となる。すな わち、アンケート結果とおおむむ䄈した評価となる。このことか ら、横山，黒田らの評価指標の CLT 造床に対寸る適用性が確認で きたと考えられる。

\section{CLT 造実在床の歩行振動の解析方法の検討}

\section{1 固有值解析および静荷重に対する応答解析}

5.1 で述べた対象床の有限要素法による解析モデルを作成した。

Fig. 6 に、解析モデルの概要を示す。当モデルでは、図に示すよ うに、I5を中心に $500 \mathrm{~mm}$ 間隔で要素を設定するとともに、スプラ イン接合部および壁の位置に適宜要素を追加した。このモデルを用 い、材料の物性值や接合部の固定度などを種々変化させながら固有 振動数, 振動モードおよび静的荷重載荷時の変形を求め、測定結果

Table 2 Measured and analyzed result of $V L_{\max }$ and $V L T$ 


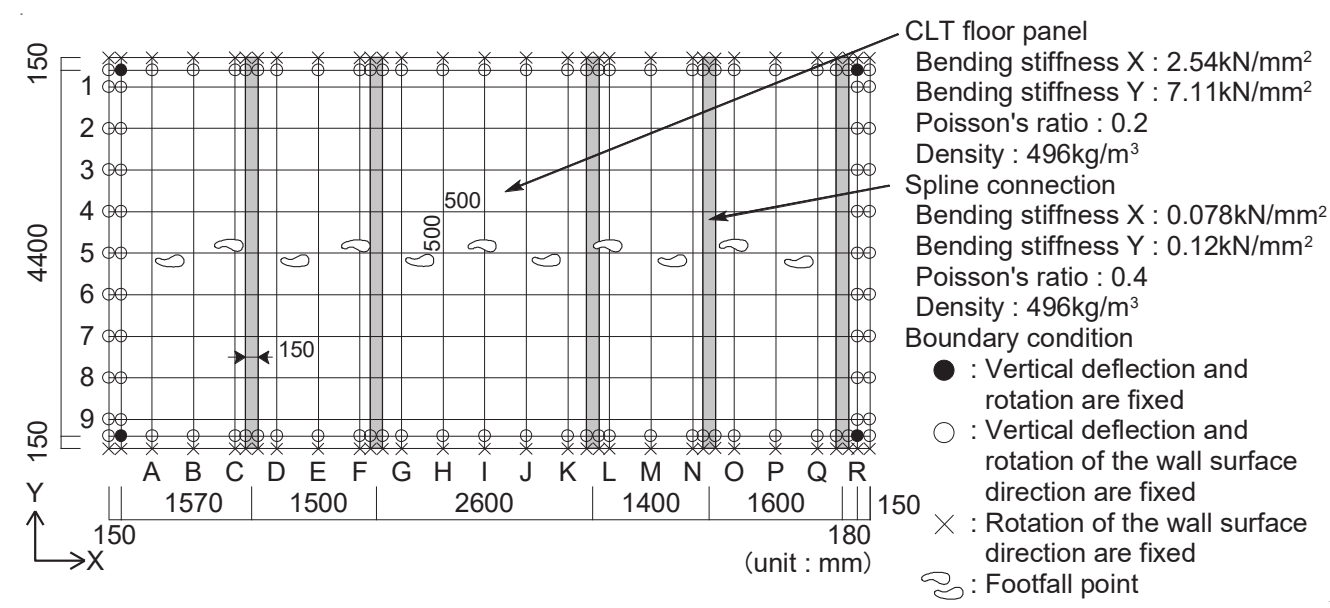

Fig. 6 Outline of finite element model of investigated CLT floor

と比較する検討を繰り返した結果、最終的に、以下に述べるモデル

で、測定結果をおおむね再現できることが明らかとなった。

\section{(1)CLT 床版の曲げ剛性および密度}

曲げ剛性については、CLT 床版の異方性を考慮しなければ測定 結果を再現できないこと、および構造設計用の規格值では低すぎる ことを確認したうえで、当該 CLT を対象とした材料試験の結果得 られた值である $7.11 \mathrm{kN} / \mathrm{mm}^{2}$ (強軸方向)拉よび $2.54 \mathrm{kN} / \mathrm{mm}^{2}$ (弱軸方 向)とした。また、密度も、材料試験の結果得られた值である $496 \mathrm{~kg} / \mathrm{m}^{3}$ とした。

\section{(2)CLT 床版のポアソン比}

CLT 床版のポアソン比の測定例は見当たらないことから、一般 的な木材のポアソン比とされる 0.4 を中に種々変化させ、測定結 果を再現できる值を同定した結果、0.2 とした。

\section{(3)スプライン接合部の曲げ剛性および密度}

曲げ剛性は、CLT 床版の上面 2 プライの切り欠き部に固定され た構造用合板およびラミナの值とした。一方、密度は、CLT 床版 と同じ值とした。これは、使用した構造用合板の材料試験值が取得 できなかったことと、床版全体の厚さに占める構造用合板の厚さの 割合は $1 / 7$ であるため全体をCLT として解析しても結果に大きな 差は生じないとみなしたことによる。

\section{(4)床版と壁の接合部}

5.1で述べた通り CLT 床版が壁の上に載っていることと、5.2 で 述べた通り床版のみをモデル化する場合壁の位置での床版の固定度 はピン支持とみなすのが適当と推察されたことから、床版の支持方 法は、外壁の場合、壁内側の位置にある節点にてピン支持とし、内 壁の場合、壁内側および外側の位置にある節点にてピン支持とし た。また、外壁, 内壁ともに、壁の両側の位置にある節点にて、壁 面内方向の回転を拘束した。

以上のモデルによる解析の結果得られた 1 3 次の固有振動数お よび振動モードを、Fig. 4 の(b)に示す。図に示した振動モード は、測定結果同様、I5 を基準として描いたものである。この図と (a)の測定結果を比較すると、固有振動数は 4 10\%の差となって いること、また振動モードの形状も測定結果から推察された対象床 全体の振動モードの形状と一致していることがわかる。

つぎに、I5 に質量 $100 \mathrm{~kg}$ の重錘に相当する $980 \mathrm{~N}$ の荷重を静的 に載荷したときの I2〜I5, I5～Q5 の変形の解析結果を、Fig. 3 に
破線で示す。図の破線と実線で示した測定結果を比較すると、I5 の変形量は $9 \%$ 差となっており、かつ変形の広がりも列方向, 行 方向ともに近似していることから、対象床の変形をその広がりも含 めて再現できていることがわかる。

以上より、作成した解析モデルで、対象床の変形特性および振動 特性をおおむね再現できていることがわかる。

\section{2 歩行応答解析}

6. 1 で作成した解析モデルを用い、歩行加振力を入力したときの 応答を求めた。歩行路と測定点の組み合わせは、 5.4 で述べた 4 種 とした。具体的には、例えば歩行路 5 行, 測定点 I4 の場合、Fig. 6 に足形で示寸歩行者の着地位置(歩幅 $750 \mathrm{~mm}$ ) に新たに節点を追加 したうえで、各点に 1 歩分の歩行荷重を 0.5 秒 $(2 \mathrm{~Hz})$ ずつずらしな がら入力し、I4 での加速度・時間曲線を求めた。節点の追加にあ たっては、固有值解析結果にほとんど影響しないことをあらかじめ 確認した。減衰定数は、 5.3 の結果を参考に、床上に 2 名の受振者 が乗った状態での值である $5.1 \%$ 、高次まで一律に採用した。

はじめに、日本建築学会「建築物荷重指針」23)および設計資料 24) に示された Fig. 7 に示す 1 歩分の歩行荷重を各着地位置に入力した ところ、着地時に励起される 1 歩ごとの加速度の最大值は、測定結 果の $1 / 2 \sim 2 / 3$ となった。この原因について検討したところ、以下 の事項が考察された。

Fig. 8 に、入力した歩行加振力の $1 / 3$ オクターブバンド分析結果 の例(歩行路 5 行の場合)を で示す。歩行加振力の振動数特性のう ち、 $10 \mathrm{~Hz}$ 程度以上の成分には、Fig. 7 に示寸ピーク $p_{1}$ における荷

Condition of foot contact

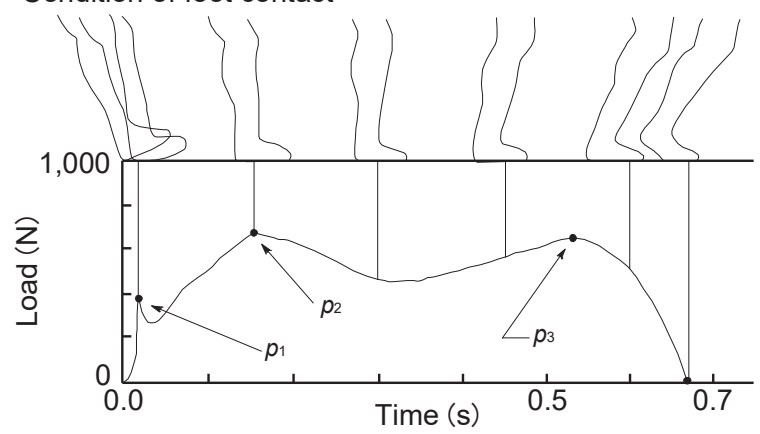

Walker's weight: $600 \mathrm{~N}$, On a rigid floor, Wearing socks

Fig. 7 Footfall force shown in Recommendations for Loads on Buildings ${ }^{22)}$ and Guidebook ${ }^{23)}$ 


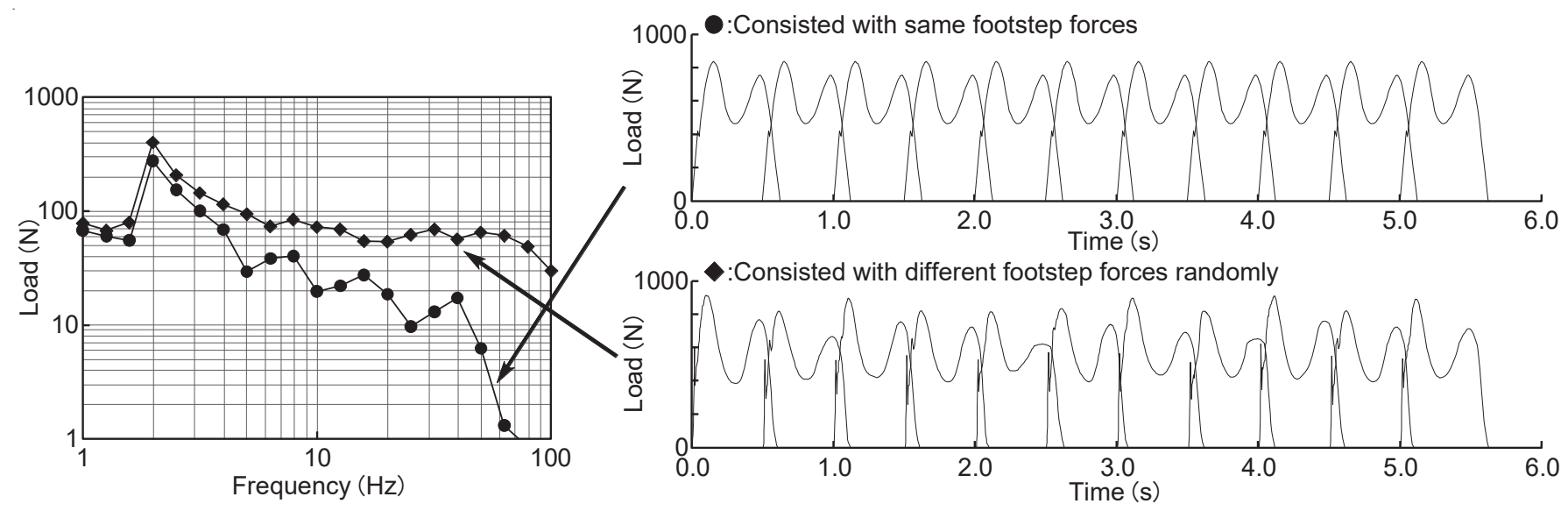

Fig. 8 Result of $1 / 3$ oct. band analysis of walking force

重の大きさおよび作用時間に加え、ピーク $p_{1}$ から $p_{2}$ に至る部分の 荷重・時間曲線の形状が大きく影響する。しかし、荷重指針に示さ れた歩行荷重は、この部分の細かな荷重の増減を単純化し滑らかに つないだ波形となっているため、結果的に $10 \mathrm{~Hz}$ 程度以上の成分が 大きく低下している。また、同一の 1 歩分の荷重が単純に繰り返さ れた歩行加振力であるため、優勢な振動数成分と劣勢な振動数成分 が明確に出現しており、振動数特性に偏りが生じている。このよう な歩行加振力を固有振動数 $10 \mathrm{~Hz}$ 程度以上の床の歩行振動の予測に 用いると、応答を全体的に小さく見積もってしまううえに、固有振 動数のわずかな違いにより共振, 反共振現象が発生し、応答が大き く変動する不安定な結果を招くこととなる。

以上より、上記のような単純化を行わない、より現実に近い歩行 加振力を設定する必要があると考え、 5.4 で述べた歩行試験に用い た歩行者の 1 歩分の荷重を 50 サンプル測定し、これらの中から所 定の歩数分のサンプルをランダムに選定した歩行加振力を、歩行路 ごとに 5 パターン作成した。歩行者の履物, 歩調は、 5.4 で述べた と同様くつ下， $2 \mathrm{~Hz}$ とした。このようにして作成した歩行加振力の 1/3 オクターブバンド分析結果の例を、Fig. 8 にで示す。図に は、歩行路が 5 行の場合の 11 歩分の歩行加振力 5 パターンの平均 を示した。図より、 $10 \mathrm{~Hz}$ 程度以上の成分はのより大きくなってお り、かつ偏りもなくなっていることがわかる。よって、これらの歩 行加振力を上述の解析モデルに入力したところ、Fig. 5 の下段に例 示するように、 1 歩ごとの加速度の最大值は、上段の測定結果と比 較的近似した值となった。また、これらの解析結果からパターンご とに $V L_{\max }$ および $V L T$ を算出しその平均を測定結果と比較したと ころ、Table 2 に示寸通り、VLmax は 0〜 $4 \mathrm{~dB} 、 V L T$ は $2 \sim 5 \mathrm{~dB}$ の 差で予測できていることが明らかとなった。VLT の差が $V L_{\max }$ よ り大きいのは、Fig. 5 に示寸通り、解析結果では測定結果でみられ る一度振動が減衰した後の増幅(以降“摇れ戻し”之記す)が再現で きていないことによるものと思われる。この摇れ戻しは、おもに壁 からの反射波によるものと思われるが、反射波の影響を再現できる 解析モデルの確立は、今後の課題とする。

以上より、作成した解析モデルと歩行加振力で、対象床の歩行振 動を、振幅の最大值を中心におおむ称再現できることが明らかとな った。

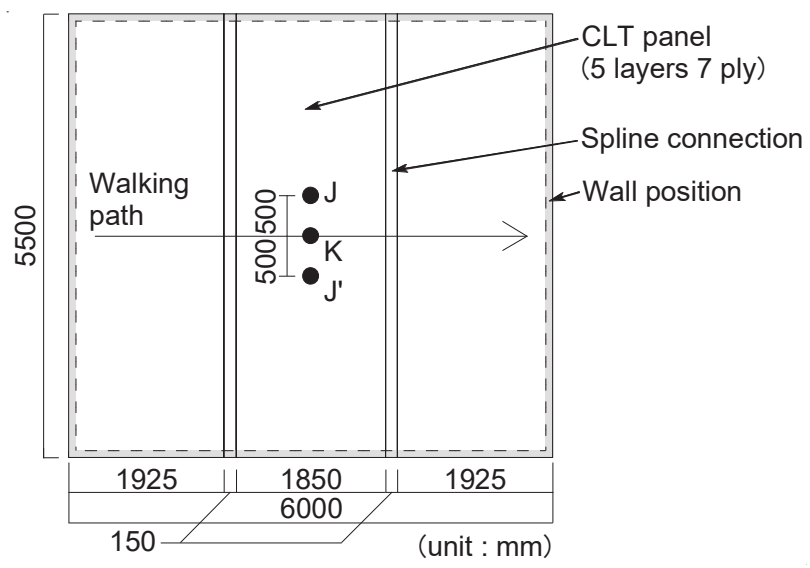

Fig. 9 Outline of CLT specimen floor

\section{CLT 造試験体床を用いた床壁接合部の接合方法の影響の検討}

\section{1 CLT 造試験体床の概要}

床壁接合部の接合方法の違いが変形特性，振動特性，歩行振動に およぼす影響を把握するために、接合方法が異なる 3 種の CLT 造 試験体床を作製した。試験体床の概要を Fig. 9 に示す。試験体床 は、いずれも幅 $2 \mathrm{~m}$ ，厚さ $210 \mathrm{~mm}$ ，スパン $5500 \mathrm{~mm}$ (壁外側間)の スギ材製 5 層 7 プライの CLT 床版 3 枚で構成されている。隣接す る床版同士の接合部は、上面 1 プライを幅 $150 \mathrm{~mm}$ 切欠き、厚さ $28 \mathrm{~mm}$ のカラマツ材製構造用合板 2 級を長さ $140 \mathrm{~mm}$ のビスで固定 した、スプライン接合となっている。床版は、周囲に設けられた高 さ $880 \mathrm{~mm}$ ，厚さ $90 \mathrm{~mm}$ の CLT 造壁の上に載っている。なお、壁 位置の床上には、上部構造物を模した質量約 $270 \mathrm{~kg} / \mathrm{m}$ を載荷し た。床壁接合部の接合方法は、以下の 3 種とした。

(1)L 字金物接合：5.1 で述べた CLT 造実在床と同一の L 字金物を 床版下端，壁内側に $850 \mathrm{~mm}$ 間隔で取り付けた接合

(2)ビス鉛直打ち接合 : 長さ $290 \mathrm{~mm}$ のビスを床版上の壁心の位置か ら鉛直方向に $300 \mathrm{~mm}$ 間隔で打ち込んだ接合

(3)ビス斜め打ち接合 : 長さ $140 \mathrm{~mm}$ のビスを床版側面の下から 2 プ ライ目と 3 プライ目の境界の位置から斜め下 $45^{\circ}$ の方向に $200 \mathrm{~mm}$ 間隔で打ち込んだ接合

\section{2 静的載荷試験}

図の $\mathrm{K}$ 点に質量 $100 \mathrm{~kg}$ の重錘を載荷し、K 点での変形を測定し た。変形は、変位計を床版の裏面に設置して測定した。 
Table 3 Results of experiments of CLT specimen floor

\begin{tabular}{|c|c|c|c|}
\hline & $\begin{array}{l}\text { L-shaped } \\
\text { angle } \\
\text { connection }\end{array}$ & $\begin{array}{c}\text { Vertical } \\
\text { screw } \\
\text { connection } \\
\end{array}$ & $\begin{array}{c}\text { Diagonal } \\
\text { screw } \\
\text { connection } \\
\end{array}$ \\
\hline $\begin{array}{l}\text { Deflection by } \\
\text { static loading }(\mathrm{mm})\end{array}$ & 0.185 & 0.202 & 0.212 \\
\hline $\begin{array}{l}\text { First natural } \\
\text { frequency }(\mathrm{Hz})\end{array}$ & 17.0 & 16.5 & 16.0 \\
\hline \begin{tabular}{l|l} 
Damning & with no person \\
\end{tabular} & 3.2 & 3.0 & 2.6 \\
\hline Dampıng with one person & 4.1 & 5.2 & 5.4 \\
\hline with two people & 5.4 & 4.8 & 5.4 \\
\hline$V L T(\mathrm{~dB})$ & 85 & 83 & 83 \\
\hline
\end{tabular}

\section{3 動的加振試験}

図の $\mathrm{K}$ 点をハンマーで加振した際の振動を、 $\mathrm{K}$ 点と $\mathrm{J}$ 点の床上 に加速度計を設置して測定した。測定結果を周波数分析し、固有振 動数を求めた。つぎに、減衰特性を把握する目的で、 $\mathrm{K}$ 点をハン マーで加振した際の $\mathrm{K}$ 点における加速度を、床上に人間が乗って いない状態, $J$ 点に 1 名の受振者が乗った状態, $J$ 点と $J$ 点に計 2 名の受振者が乗った状態の 3 条件で測定した。受振者の体重, 姿 勢および測定回数は 5.3 と同一とし、加速度 ・ 時間曲線の測定結果 から減衰定数を算出した。

\section{4 歩行試験}

図に矢印で示す歩行路を歩行者が $2 \mathrm{~Hz}$ で歩行した際の振動を、 $\mathrm{J}$ 点の床上に加速度計を設置して測定した。測定は、J 点に受振者 1 名が乗った状態で実施した。歩行者の履物, 歩調、歩行者, 受振 者の体重および測定回数は 5.4 と同一とし、測定の結果得られた加 速度・時間曲線から VLTを算出した。

\section{5 試験結果および接合方法の影響の検討}

Table 3 に、試験結果を示す。表に示すように、静的載荷時の変 形はL字金物接合が最も小さく、ビス鉛直打ち接合, ビス斜め打ち 接合の順に大きくなっており、1 次固有振動数は同じ順で小さくな っている。このことから、接合部の固定度は L 字金物接合が最も高 く、ビス鉛直打ち接合, ビス斜め打ち接合の順に低いことがわか る。ここで、静的載荷時の変形量の差は $13 \%$ 程度、固有振動数の
差は $6 \%$ となっている。

また、減衰定数は、5.3 で述べたCLT 造実在床と同様、いずれの 試験体床でも床上の受振者数が増えるにしたがって大きくなってい る。ここで、床上に 2 名の受振者が乗った状態での減衰定数は 4.8 5.4\%であった。なお、 5.3 で述べた CLT 造実在床の減衰定 数も、この範囲内となっている。

さらに、歩行試験結果から算出された $V L T$ の 3 種の試験体床間 での差は、 $2 \mathrm{~dB}$ となっている。

このように、3 種の試験体床での測定結果には、床壁接合部の接 合方法の違いによる差がみられるが、その差は解析の精度と比較し て小さいことから、固定度の違いを解析モデルに反映させて上記の 差を再現するのは困難と考えられる。この結果は、歩行振動のよう な微細な振幅領域では、構造設計で扱う荷重, 変形の領域と比較し て、床壁接合部の接合方法の影響は小さいことを示唆している。

以上より、本研究では、6.1 で述べた解析モデルにおける床壁接 合部での床版の支持方法を踏襲し、減衰定数は高次まで一律に $5 \%$ としたうえで、スパン表例示のための解析を実施することとした。

\section{CLT 造床のスパンと歩行振動の関係に関する解析的検討 8. 1 解析の概要}

5. 〜7. で得られた知見に基づいて、一般的な仕様と考えられる CLT 造床の解析モデルを作成した。Fig. 10 に、作成したモデルの 概要を示す。当モデルは、幅 $2 \mathrm{~m}$, 厚さ $210 \mathrm{~mm}$, スパン $L$ の CLT 床版 5 枚で構成されている。図には、例として、 $L=5.5 \mathrm{~m}$ の場合の モデルを示した。なお、床版の枚数については、幅 $2 \mathrm{~m}$ の床版 3 枚 とした場合の検討も行ったが、結果は 5 枚とした場合とほとんど異 ならなかった。

CLT 床版については、スギ材製 5 層 7 プライと 7 層 7 プライの 2 種 について検討することとした。それぞれの曲げ剛性，密度は、図に 示寸通りである。これらは、当該 CLT を対象とした材料試験の結 果から得られた值である。また、ポアソン比は、 7 層 7 プライの床 版では 6.1 で同定した 0.2 とし、5 層 7 プライの床版では別途 7.1 の

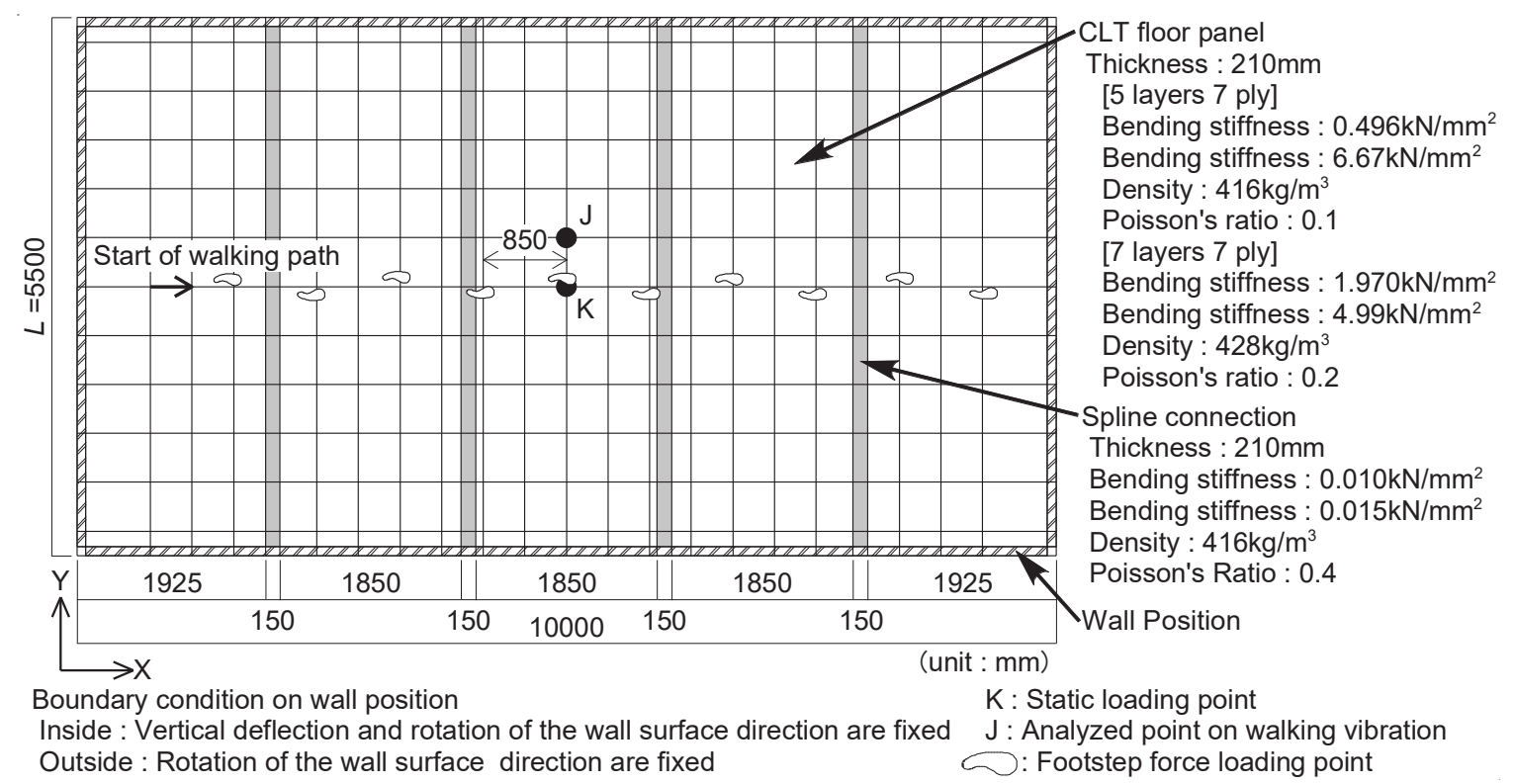

Fig. 10 Outline of finite element model for span table 
Table 4 Analyzed results for span table

\begin{tabular}{|c|c|c|c|c|c|}
\hline $\begin{array}{l}\text { CLT } \\
\text { floor } \\
\text { panel }\end{array}$ & $\begin{array}{l}\text { Span } \\
\qquad \\
(\mathrm{m})\end{array}$ & \begin{tabular}{|c|} 
First natural \\
frequency \\
$f_{0}$ \\
$(\mathrm{~Hz})$
\end{tabular} & $\begin{array}{c}\text { Deformation } \\
\text { by } 980 \mathrm{~N} \text { static } \\
\text { loading } D_{100} \\
(\mathrm{~mm})\end{array}$ & $\begin{array}{l}V L T \\
(\mathrm{~dB})\end{array}$ & $\begin{array}{l}\text { Evaluation level } \\
\text { of annoyance* } \\
\text { [達成される気になり } \\
\text { 具合の評価水準] }\end{array}$ \\
\hline \multirow{10}{*}{$\begin{array}{c}5 \text { layers } \\
7 \text { ply }\end{array}$} & 2.0 & 108.9 & 0.020 & 62.2 & (6) \\
\hline & 2.5 & 68.9 & 0.033 & 67.4 & (6) \\
\hline & 3.0 & 47.2 & 0.048 & 71.9 & (6) \\
\hline & 3.5 & 34.3 & 0.067 & 75.6 & (6) \\
\hline & 4.0 & 26.1 & 0.089 & 78.9 & (6) \\
\hline & 4.5 & 20.5 & 0.116 & 79.9 & (5) \\
\hline & 5.0 & 16.6 & 0.147 & 82.4 & (4) \\
\hline & 5.5 & 13.7 & 0.182 & 84.2 & (4) \\
\hline & 6.0 & 11.6 & 0.222 & 86.5 & less than (4) \\
\hline & 6.5 & 9.9 & 0.267 & 89.6 & less than (4) \\
\hline \multirow{9}{*}{$\begin{array}{c}7 \text { layers } \\
7 \text { ply }\end{array}$} & 2.0 & 92.0 & 0.020 & 61.7 & (6) \\
\hline & 2.5 & 58.1 & 0.031 & 68.0 & (6) \\
\hline & 3.0 & 39.7 & 0.047 & 73.2 & (6) \\
\hline & 3.5 & 28.9 & 0.068 & 78.3 & (6) \\
\hline & 4.0 & 22.0 & 0.094 & 79.5 & (5) \\
\hline & 4.5 & 17.3 & 0.126 & 82.0 & (4) \\
\hline & 5.0 & 14.1 & 0.164 & 84.8 & (4) \\
\hline & 5.5 & 11.6 & 0.208 & 86.9 & less than (4) \\
\hline & 6.0 & 9.8 & 0.259 & 89.5 & less than (4) \\
\hline
\end{tabular}

$*$ In the residential room [住居の居室]

Table 5 Span table of CLT floor from the viewpoint of walking vibration

\begin{tabular}{|c|c|c|c|}
\hline \multirow[b]{2}{*}{$\begin{array}{c}\text { CLT } \\
\text { floor panel }\end{array}$} & \multicolumn{3}{|c|}{$\begin{array}{l}\text { Evaluation level of annoyance* } \\
\text { [達成される気になり具合の評価水準 }]\end{array}$} \\
\hline & $\begin{array}{l}\text { (6)Between } \\
\text { not annoyed and } \\
\text { slightly annoyed } \\
\text { [全く気にならないと } \\
\text { や気になるの間] }\end{array}$ & $\begin{array}{l}\text { (5) Slightly annoyed } \\
\text { [やや気になる] }\end{array}$ & $\begin{array}{l}\text { (4)Between } \\
\text { slightly annoyed } \\
\text { and fairly annoyed } \\
\text { [やや気によると } \\
\text { かなり気にになるの間] }\end{array}$ \\
\hline 5 layers 7 ply & 4.0 & 4.5 & 5.5 \\
\hline 7 layers 7 ply & 3.5 & 4.0 & 5.0 \\
\hline
\end{tabular}

Table 6 Span table of CLT floor from the viewpoint of structural safety ${ }^{26), 27)}$

\begin{tabular}{|c|c|c|}
\hline \multirow{2}{*}{$\begin{array}{c}\text { CLT } \\
\text { floor panel }\end{array}$} & \multicolumn{2}{|c|}{$\begin{array}{c}\text { Application } \\
\text { [用途] }\end{array}$} \\
\cline { 2 - 3 } & $\begin{array}{c}\text { General house } \\
\text { [一般住宅] }\end{array}$ & $\begin{array}{c}\text { Apartment } \\
\text { [共同住宅] }\end{array}$ \\
\hline 5 layers 7 ply & 5.297 & 5.138 \\
\hline 7 layers 7 ply & 3.986 & 3.827 \\
\hline
\end{tabular}

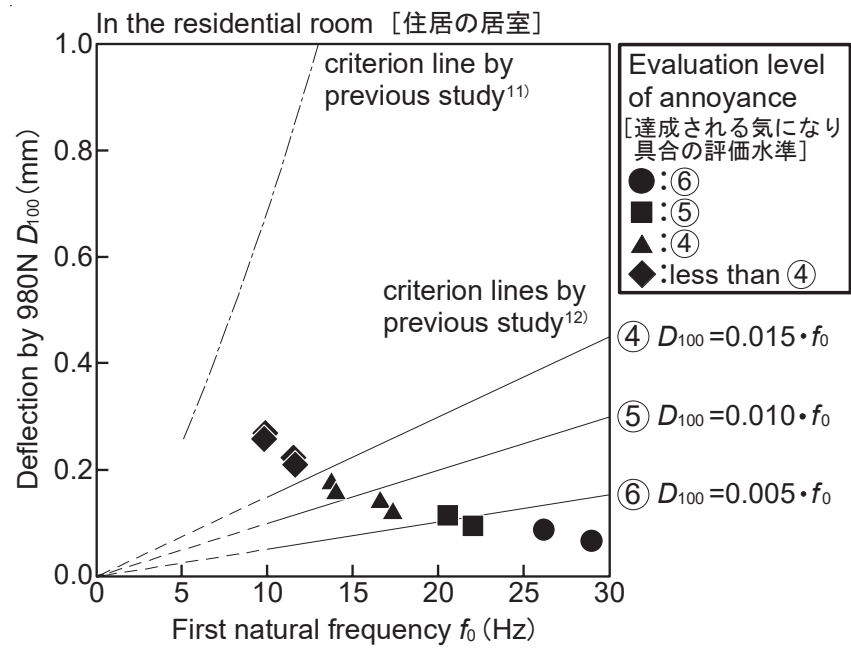

Fig. 11 Relationship among $f_{0}, D_{100}$, and evaluation of walking vibration
試験体床を解析モデル化して同定した結果に基づいて 0.1 とした。 隣接する床版同士の接合は、7.1 で述べた仕様のスプライン接合と した。減衰定数および床壁接合部における床版の支持方法は 7.5 で 述べた通りとし、壁位置の床上には 7.1 と同様上部構造物を模した 質量を載荷した。なお、積載荷重は、通常の歩行振動の予測評価の 場合と同様 0 とした。

解析は、 $L=2.0 \mathrm{~m}$ から開始し、 $0.5 \mathrm{~m}$ ずつ増大させながら、1 次 固有振動数 $f_{0}$ 、および $\mathrm{K}$ 点に $980 \mathrm{~N}$ の荷重を静的に載荷した時の変 形量 $D_{100}$ を求めるとともに、図に足形で示寸位置に 6.2 で述べた方 法で作成した 10 歩分の歩行加振力を 5 パターン入力した際の $\mathrm{J}$ 点 での加速度・時間曲線を求め、VLT の平均を算出した。解析は、 $f_{0}$ が倍調波共振が発生する可能性が高くなる $\left.{ }^{25}\right) 10 \mathrm{~Hz}$ を下回った段 階で終了した。

\section{2 解析結果}

解析結果をTable 4 に示寸。表に示寸通り、 $f_{0}$ が $10 \mathrm{~Hz}$ を下回ら ないスパンの最大值は、 5 層 7 プライでは $6.0 \mathrm{~m}, 7$ 層 7 プライでは $5.5 \mathrm{~m}$ であった。また、各スパンで算出された $V L T$ をFig. 1 に示す 木造床の歩行振動の評価指標と照合した結果を、表の「達成される 気になり具合の評価水準」の欄に示す。例えば、 5 層 7 プライで スパンが $5.5 \mathrm{~m}$ の場合、VLTは $84.2 \mathrm{~dB}$ であり、この值を Fig. 1 と照合すると、気になり具合は“(5)やや気になる” と “4 ……”の間となるため、達成される評価水準は(4)となる。

\section{3 歩行振動からみた CLT 造床のスパン表の例示}

Table 4 より、住居の居室における要求水準として一般的な範囲 内と思われる (4) (6)の各評価水準が達成される最も大きい $L$ を求 め、Table 5 に示す。本研究では、Table 5 を、歩行振動の気にな り具合からみた CLT 造床のスパン表として例示寸る。表に示寸通 り、居住性からみたスパン表は、構造安全性からみたスパン表と異 なり、使用者の要求水準に応じた数段階のスパンが提示される点に 特徴がある。ちなみに、構造安全性の観点から可能なスパンの最大 值を文献 26),27)にしたがって算出し、Table 6 に示す。Table 5 およ びTable 6 より、例えば 5 層 7 プライの場合、歩行振動に対する要 求水準が “(5)やや気になる” 以上だと、可能なスパンの最大值は歩 行振動の観点から定まることがわかる。

なお、例示したスパン表は、限られた仕様の CLT 造床を対象と した検討により求めたものであり、あくまでも一例であることに留 意する必要がある。

\section{4 固有振動数と集中荷重載荷時の変形量を用いた設計資料の適 用性の検討}

3.で述べた通り、 $\mathrm{Hu} ら$ 11)および西谷ら ${ }^{12)}$ は、所定の評価水準 よりよい評価が得られる床の範囲を、床の固有振動数と集中荷重載 荷時の変形量を用いた式で提示している。これらの式を、変形量と 固有振動数からなる平面上に表したものが、Fig. 11 である。図の 縦軸は床中央に $980 \mathrm{~N}$ の集中荷重を載荷したときの床中央の変形 量、横軸は床の 1 次固有振動数であり、一点鎖線は $\mathrm{Hu}$ らが提示し た “marginal”よりよい評価が得られる床の範囲の上限、(4)〜 (6)の 実線は西谷らが提示した各評価水準よりよい評価が得られる床の範 囲の上限を表す。ここで、 $\mathrm{Hu} ら$ の設計資料では $1 \mathrm{kN}$ 載荷時の変形 量を用いているが、980N 載荷時とほぼ同值とみなしてそのまま表 示している。 
この図に、Table 4 に示した CLT 造床の $f_{0}$ および $D_{100}$ の解析結 果をプロットして示す。図の記号は、当該床で達成される評価水準 により分類したものである。図より、評価水準(5)が達成されない で示寸点の一部が(5)の実線より下側にあるものの、(4)が達成されな いと達成されるムは(4)の実線で分類できているなど、全体的にみ て、各プロットの記号と (4)〜(6)の実線はおおむ敉合していること がわかる。すなわち、CLT 造床に対しても、西谷らの設計資料が おおむね適用できることがわかる。一方、 $\mathrm{Hu} ら$ らの “marginal”の 上限を表す一点鎖線は、評価水準(4)が達成されないくよりも上側に あり、この線を許容基準とすると、(4)が達成されない床も許容され ることがわかる。ただし、床振動に対する人間の評価はそれを定量 化する際のアンケートや検査などの条件により変化することから、 許容基準の妥当性については、実在建築物における居住後評価など に関するデータの蓄積を待つ必要があると考えられる。

\section{9. おわりに}

木造床における歩行振動の予測評価の枠組み構築を最終的な目的 とした研究の第一段階として、CLT 造床を対象に、歩行振動の予 測方法確立のための知見を蓄積するとともに、木造床の歩行振動の 評価指標を適用してスパン表を例示することを目的とした本研究の 結論をまとめると、以下の通りである。

- CLT 造床の歩行振動の予測解析では、床版の異方性を考慮する とともに、床版の曲げ剛性, 密度については、構造設計用の規格 值ではなく、当該 CLT を対象とした材料試験の結果得られた值 を用いると、測定結果とよい対応が得られる。

・下階の壁の上に床版が載る形式の床壁接合部を有する CLT 造床 では、接合部での床版の固定度は、外壁の場合、壁内側の位置に ある節点にてピン支持、内壁の場合、壁内側および外側の位置に ある節点にてピン支持とすることで、測定結果とよい対応が得ら れる。また、接合方法の違いは、歩行振動のような微細な振幅領 域では、大きくは影響しない。

- CLT 造床の減衰は、一般的な木造床と同様、床上に乗っている 人体の影響を受け、乗っている人数が増えるにしたがって大きく なる。床上に 2 名が乗った場合の CLT 造床の減衰定数は、 $5 \%$ 程 度である。

・ 木造床の歩行振動の予測解析では、歩行加振力については、同一 かつ単純化された 1 歩分の荷重が繰り返される人工的な加振力で はなく、より現実に近い 1 歩ごとのばらつきや細かな荷重の増減 を考慮した加振力を用いると、測定結果とよい対応が得られる。

・スパンを変数とした解析的検討により、CLT 造床で発生する歩 行振動を予測し、横山, 黒田ら ${ }^{3), 4)}$ が提示した評価指標と照合す ることにより、歩行振動からみた CLT 造床のスパン表を、数段 階の要求水準ごとに例示した。

・ 上記の解析的検討結果と、Hu ら ${ }^{11}$ および西谷ら ${ }^{12)}$ が提示した床 の固有振動数と集中荷重載荷時の変形量を用いた設計資料との整 合性を検討した。その結果、後者とは整合する一方、前者とは整 合せず、後者と比較してより大きな振動でも許容される設計資料 となっていることを明らかにした。

以上であるが、本研究は限られた仕様の CLT 造床を対象に歩行 振動の予測評価の枠組み構築を試行したものであり、例示したスパ
ン表はあくまでも一例であることに留意する必要がある。

\section{謝辞}

本研究は、「平成 27 年度林野庁委託事業 CLT 等新たな製品・ 技術の開発・普及事業(CLT 住性能向上開発研究)」の歩行振動性能 検討 WG、および「平成 27 年度補正林野庁補助事業 地域材利用 拡大緊急対策事業(木材の新規用途の導入促進)のうち地域の特性に 応じた木質部材・工法の開発・普及等支援事業」の歩行振動WGの 活動の一環として実施されたものである。研究を進めるにあたり 種々御助言, 御協力いただきました各 WG 委員ならびに日本 CLT 協会の関係各位、CLT 造実在床および試験体床での測定に種々御 協力いただきました協同組合オホーツクウッドピアおよび国立研究 開発法人森林研究・整備機構森林総合研究所の関係各位に、謝意を 表します。

\section{参考文献}

1)Yutaka Yokoyama: The Measurement Method of Actual House Floor Vibration and the Criterion to Prevent Complaint from Occupants, Journal of Structure and Construction Engineering (Transactions of AIJ), No.546, pp.17-24, 2001.8

横山裕：苦情発生の有無からみた実在住宅床振動の測定条件，境界值の提 示，日本建築学会構造系論文集，第 546 号,pp.17-24, 2001.8

2)Architectural Institute of Japan: Guidelines for the evaluation of habitability to building vibration, 2004.5

日本建築学会：建築物の振動に関する居住性能評価指針・同解説, 2004.5

3)Yutaka Yokoyama, Eiichi Kuroda, Shintaro Fukuda: A Fundamental Study of Performance Values in High Stiffness Floors, A Method to Evaluate the Habitability of Walking-induced Vibration on Long-span Timber Floors Part 2, Journal of Environment Engineering (Transactions of AIJ), Vol.80, No.712, pp.509-518, 2015.6

横山裕, 黒田瑛一, 福田眞太郎：剛性の高い床に適用する性能值に関する基 礎的検討，木造大スパン床の歩行振動の居住性からみた評価方法(その 2), 日 本建築学会環境系論文集, 第 80 巻, 第 712 号, pp.509-518, 2015.6

4)Eiichi Kuroda, Shintaro Fukuda, Yutaka Yokoyama: Fundamental Study on Method to Evaluate the Habitability of Walking-induced Vibration on Long-span Timber Floors, Part 6 Reinvestigation of Performance Values based on Vibration Level, Summaries of Technical Papers of Annual Meeting, Architectural Institute of Japan, D-1, pp.373-374, 2015.9 黒田瑛一，福田眞太郎，横山裕：居住性からみた木造大スパン床の歩行振 動の評価方法に関する基礎的研究，その 6 振動レベルに基づいた性能值に 関する再検討, 日本建築学会大会学術講演梗概集, D-1, pp.373-374, 2015.9 5)Architectural Institute of Japan: Standard for the Evaluation of Habitability to Building Vibration, 2018.11

日本建築学会：建築物の振動に関寸る居住性能評価規準・同解説, 2018.11

6)Yuhei Koyama, Shunsuke Naganuma, Hitoshi Matsushita, Shintaro Fukuda, Yutaka Yokoyama: Fundamental Study on Walking Vibration of Cross Laminated Timber Floor, Summaries of Technical Papers of Annual Meeting, Architectural Institute of Japan, D-1, pp.411-412, 2016.8

小山雄平，長沼俊介，松下仁士，福田眞太郎，横山裕：CLT 造建築物床の歩 行振動性状に関する基礎的研究, 日本建築学会大会学術講演梗概集, D-1, pp.411-412, 2016.8

7)Kazuma Matsuo, Yuhei Koyama, Shintaro Fukuda, Yutaka Yokoyama: Presentation of Example of Span Table of Cross Laminated Timber Floor from the Viewpoint of Walking Vibration, Summaries of Technical Papers of Annual Meeting, Architectural Institute of Japan, C-1, pp.595-596, 2017.8

松尾和午, 小山雄平, 福田眞太郎, 横山裕: 歩行振動からみた CLT 造建 築物床のスパン表の例示，日本建築学会大会学術講演梗概集，C-1, pp.595-596, 2017.8

8)Hitoshi Matsushita, Shunsuke Naganuma, Ryota Inoue, Yutaka 
Yokoyama: Performance Values Applicable to Vertical Vibrations Occurring from Various Excitation Sources, Journal of Environment Engineering (Transactions of AIJ), Vol.81, No.720, pp.153-162, 2016.2 松下仁士, 長沼俊介, 井上竜太, 横山裕：種々の加振源による鉛直振動に 適用できる性能值, 日本建築学会環境系論文集, 第 81 巻, 第 720 号, pp.153-162, 2016.2

9)Architectural Institute of Japan: Standard for Structural Design of Timber Structures, p.120, 2006.12

日本建築学会: 木質構造設計規準 - 同解説, 一許容応力度 - 許容耐力設計 法一, p.120, 2006.12

10) European Committee for Standardization: Eurocode 5: Design of timber structures - Part 1-1: General - Common rules and rules for buildings, EN 1995-1-1:2004+A1, 2008.6

11)Lin Hu, Sylvain Gagnon: Controlling Cross-Laminated Timber (CLT) Floor Vibrations: Fundamentals and Method, World Conference on Timber Engineering Auckland 2012, 269-275, 2012.7

12)Shinsuke Nishitani, Hideaki Moritoki, Eiichi Kuroda, Yutaka Yokoyama: Study on Design Method for Long-span Timber Floors to Prevent Vibration Hazard, Relationship between Assessment of Walking Vibration and Vibration Characteristics of Long-span Timber Floors, Summaries of Technical Papers of Annual Meeting, Architectural Institute of Japan, D-1, pp.359-360, 2015.9 西谷伸介，守時秀明，黒田瑛一，横山裕：振動障害のない木造大スパン 床の設計方法の検討, 在来軸組構法大スパン床の歩行振動の評価と固有 振動数および岡性の関係, 日本建築学会大会学術講演梗概集, D-1, pp.359-360, 2015.9

13)Ken-ichi Sugimoto, Noboru Nakamura et al.: Relationship between Vertical Load Properties of Floors and Human Sensory Evaluation of Walking Vibration in Wooden Schools and Offices I ., Static and Dynamic Properties of Large-span Wooden Floors, Mokuzai Gakkaishi, Vol.62, No.4, pp.101-107, 2016.7

杉本健一, 中村昇ら：木造校舎および事務所の床の鉛直荷重に対する性能 と歩行振動に対する感覚評価との関係(第 1 報) 木造大スパン床の静的お よび振動性状，木材学会誌, Vol.62, No.4,pp.101-107, 2016.7

14)Ken-ichi Sugimoto, Noboru Nakamura et al.: Relationship between the Vertical Load Properties of Floors and Human Sensory Evaluations of Walking Vibration in Wooden Schools and Offices II., Possibility of a Tentative Design Target for Large-span Wooden Floors according to Human Sensory Evaluations of Walking Vibration, Mokuzai Gakkaishi, Vol.63, No.2, pp.98-107, 2017.3

杉本健一，中村昇ら：木造校舎および事務所の床の鉛直荷重に対する性能 と歩行振動に対する感覚評価との関係(第 2 報) 歩行振動の感覚評価によ る木造大スパン床の設計目標提案の可能性, 木材学会誌, Vol.63, No.2, pp.98-107, 2017.3

15)Shuzo Suzuki, Eiichi Fujino, Hiroyuki Noguchi: Experimental Study on Effect of Human-load on Vertical Dynamic Characteristics of Wooden Floors (Part 1), Journal of Structure and Construction Engineering (Transactions of AIJ), No.585, pp.123-129, 2004.11

鈴木秀三, 藤野栄一, 野口弘行：木造床の鉛直振動特性に及ぼす人間 荷重の影響に関する実験的研究(第 1 報), 日本建築学会構造系論文集, 第 585 号, pp.123-129, 2004.11

16)Eiichi Fujino, Shuzo Suzuki, Hiroyuki Noguchi: Experimental Study on Effect of Human-load on Vertical Dynamic Characteristics of Wooden Floors (Part 2), Journal of Structure and Construction Engineering (Transactions of AIJ), No.589, pp.137-142, 2005.3

藤野栄一, 鈴木秀三, 野口弘行：木造床の鉛直振動特性に及ぼす人間 荷重の影響に関する実験的研究(第 2 報), 日本建築学会構造系論文集, 第 589 号, pp.137-142, 2005.3

17)Eiichi Fujino, Shuzo Suzuki, Hiroyuki Noguchi: Dynamic Response of Wooden Model Floor Subjected to Impact Force, Journal of Structure and Construction Engineering (Transactions of AIJ), No.591, pp.107-112, 2005.5

藤野栄一，鈴木秀三，野口弘行：衝撃加振力を受ける木造梁床モデルの 鉛直振動応答に関する研究, 日本建築学会構造系論文集, 第 591 号, pp.107-112, 2005.5
18)Shuzo Suzuki, Yukitaka Ihara, Eiichi Fujino: Experimental Study on Vertical Dynamic Characteristics of Light Frame Joist Floor, Journal of Structure and Construction Engineering (Transactions of AIJ), Vol.77, No.676, pp.905-910, 2012.6

鈴木秀三, 井原行孝, 藤野栄一: 木造根太床の鉛直振動特性に関する実験 的研究, 日本建築学会構造系論文集, 第 77 巻, 第 676 号, pp.905-910, 2012.6

19)Shuzo Suzuki, Yukitaka Ihara, Eiichi Fujino: Dynamic Response of Light Frame Joist Floor Subjected to Impact Force, Journal of Structure and Construction Engineering (Transactions of AIJ), Vol.77, No.677, pp.1099-1104, 2012.7

鈴木秀三, 井原行孝, 藤野栄一：衝撃加振力を受ける木造根太床の鉛 直振動変位応答に関する研究, 日本建築学会構造系論文集, 第 77 巻, 第 677 号, pp.1099-1104, 2012.7

20)Shuzo Suzuki, Yukitaka Ihara, Eiichi Fujino: Vertical Dynamic Characteristics and Impact Coefficient of Light Frame Joist Floors with Opening, Journal of Structure and Construction Engineering (Transactions of AIJ), Vol.77, No.678, pp.1265-1271, 2012.8

鈴木秀三, 井原行孝, 藤野栄一: 有開口木造根太床の鉛直振動特性と衝 撃加振特性係数に関する研究, 日本建築学会構造系論文集, 第 77 巻, 第 678 号, pp.1265-1271, 2012.8

21)Shuzo Suzuki, Yukitaka Ihara: Effects of Condition and Uneven Distributed Load on Vertical Dynamic Characteristics of Light Frame Joist Floors, Journal of Structure and Construction Engineering (Transactions of AIJ), Vol.77, No.682, pp.1897-1903, 2012.12

鈴木秀三，井原行孝：木造根太床の鉛直振動特性に及ぼす支持条件と 偏在荷重の影響に関する研究, 日本建築学会構造系論文集, 第 77 巻, 第 682 号, pp.1897-1903, 2012.12

22)Hidenori Ono, Yutaka Yokoyama: Study on Vertical Vibration of Building Floors Occurred by Human Actions and Its Indicating Method from a Viewpoint of Human Sense, In the Case that the Vibration Source and Receiver are the Same, Journal of Structure and Construction Engineering (Transactions of AIJ), No.381, pp.1-9, 1987.11

小野英哲, 横山裕：人間の動作により発生する床振動の振動感覚上の表示 方法に関する研究 一振動発生者と受振者が同じ場合一, 日本建築学会構 造系論文報告集，第 381 号, pp.1-9, 1987.11

23)Architectural Institute of Japan: Recommendations for Loads on Buildings, 2015.2

日本建築学会：建築物荷重指針・同解説, 2015.2

24)Architectural Institute of Japan: Guidebook of Recommendations for Loads on Buildings, 2016.2 日本建築学会：建築物荷重指針を活か寸設計資料 $1,2016.2$

25)Yutaka Yokoyama: Characteristics of Walking Vibration of Woody Floor and Design for Habitability, Panel Discussion Document of Structure Division (Timber Structure) of AIJ Convention, 2017.8

横山裕：歩行振動に対する木質系床の振動性状と知覚および設計, 2017 年 度日本建築学会大会(中国)構造部門(木質構造)パネルディスカッション資 料, 2017.8

26)Editing Committee of Design and Construction Manual for CLT Building: Design and Construction Manual for Building Using CLT, 2016.10

CLT 設計施工マニュアル編集委員会編: 2016 年版 CLT を用いた建築物 の設計施工マニュアル, 2016.10

27)Japan Cross Laminated Timber Association: Development of Wood Frame Construction Building Using CLT as Floor Panel, Subcontracting Business Technical Data of 2013 by Forestry Agency $2014,2017.11$

日本 CLT 協会: 床版として CLT を使用する枠組壁工法建築物の開発, 2014 年度林野庁 平成 25 年度補正委託補助事業技術データ, 2017.11 


\title{
PRESENTATION OF EXAMPLE OF SPAN TABLE OF CROSS LAMINATED TIMBER FLOOR FROM THE VIEWPOINT OF WALKING VIBRATION
}

\author{
Yuhei KOYAMA*1, Shintaro FUKUDA*2 and Yutaka YOKOYAMA*3 \\ ${ }^{* 1}$ Dept. of Architecture and Building Eng., School of Environment and Society, Tokyo Institute of Technology, M.Eng. \\ ${ }^{*}$ Assist. Prof., Dept. of Architecture and Building Eng., School of Environment and Society, Tokyo Institute of Technology, Dr.Eng. \\ ${ }^{* 3}$ Prof., Dept. of Architecture and Building Eng., School of Environment and Society, Tokyo Institute of Technology, Dr.Eng.
}

Walking vibration can cause complaints on building floor, especially on timber floor which has less weight and stiffness than concrete slab of reinforced concrete structure or steel structure. However, an evaluation index of AIJ "Guidelines for the evaluation of habitability of building vibration" developed based on studies which investigated human perception to sinusoidal vibration, and has been pointed out that this index shows stricter evaluations to walking vibrations on timber floor. On the other hand, an estimation method of walking vibration on timber floor is not established because of lack of knowledge about material parameters, setting connections and so on.

In this study, as a first step toward establishing the evaluation method and the estimation method, the vibration characteristics of a CLT floor subjected to walking vibrations was measured. Using these result, a finite element model was also created to investigate the influence of varying material properties and boundary conditions on the vibration performance of the floor. Then, via measurement three specimens of CLT floor, the influence of CLT floor-wall connection upon vibration characteristics was investigated. In conclusion, through analytical modeling based on these results, the span table of CLT floor from the viewpoint of walking vibration was presented.

The investigation procedure and result are described as follows;

1) Vibration characteristics of a CLT floor was measured through static loading test, dynamic impact test and walking vibration test. It was found that the CLT floor-wall connection is similar to pin support, and the damping ratio with two people on the CLT floor was 5.1\%. And it was also found that the VLT index which was presented as an evaluation index of walking vibration on timber floor is applicable to walking vibration on CLT floor.

2) The finite element model was created based on the investigated results, and the estimation method of walking vibration on CLT floor was considered. As a result, it was found that the walking force using for analysis should not be consisted with same footstep forces which causes bias of frequency characteristics, but be consisted with different footstep forces which has realistic frequency characteristics.

3) The vibration characteristics of three types specimens which have different CLT floor-wall connection, using L-shaped angle, using screw vertically, and using screw diagonally, were investigated. As a result, each measured result indicated that there is little difference between these specimens. In particular, the damping ratio in condition of two people on the floor were about $5 \%$ on each specimen.

4) Based on the results obtained these investigations, the CLT finite element model was created as a general CLT floor, and the analysis about the relationship between the vibration characteristics and the floor span was conducted. As a result, through collating the analyzed VLTresults with the evaluation index of previous study, the span table of CLT floor from the viewpoint of walking vibration was presented. This span table is different from the span table from the viewpoint of structural safety and can be used to suit the various requirements of the building user. Then, through comparing the analyzed results with two criteria, it corresponds to the criterion developed in Japan, but it doesn't correspond to the criterion developed in foreign country. 